\title{
TAPE MODELING OF EUCALYPTUS STEM IN CROP-LIVESTOCK- FORESTRY INTEGRATION SYSTEMS
}

\author{
Clebson Lima Cerqueira $^{1 *}$, Julio Eduardo Arce ${ }^{1}$, Diogo Guido Streck Vendruscolo ${ }^{2}$, Cícero Jorge Fonseca \\ Dolácio $^{1}$, Sérgio Vinícius Serejo da Costa Filho ${ }^{1}$, Helio Tonini ${ }^{3}$ \\ ${ }^{1}$ Federal University of Paraná, Postgraduate Program in Forest Engineering, Curitiba, Paraná, Brazil - clebsonlima10@hotmail.com*, \\ julioarce001@gmail.com, cicerodolacio@ufpr.br, sergio.vscf@gmail.com. \\ ${ }^{2}$ Proterra Florestal, Porto Esperidião, MT, Brazil -vendruscolo.dgs@ gmail.com. \\ ${ }^{3}$ EMBRAPA Agrossilpastoril, Sinop, Mato Grosso, Brazil- helio.tonini@embrapa.br.
}

Received for publication: 21/05/2018 - Accepted for publication: 11/07/2018

\begin{abstract}
Resumo
Modelagem do afilamento do fuste de eucalipto em sistema de integração Lavoura-Pecuária-Floresta. Este trabalho teve como objetivo avaliar e comparar a modelagem de efeitos mistos e redes neurais artificiais para estimar o afilamento de eucalipto em sistemas de integração Lavoura-Pecuária-Floresta (iLPF). Os dados foram coletados em uma área experimental de iLPF, implantada pela Empresa Brasileira de Pesquisa Agropecuária EMBRAPA Agrossilvipastoril, localizada no município de Sinop, Estado do Mato Grosso. Para alcançar o objetivo proposto, 165 árvores com 51 meses de idade foram cubadas para a modelagem do afilamento com modelos de efeitos mistos e redes neurais artificiais. O desempenho destas técnicas foi avaliado por meio de estatísticas de precisão e análise gráfica. A modelagem de efeitos mistos e redes neurais artificiais são eficientes e recomendadas para estimativa do afilamento de eucalipto em sistema de integração Lavoura-PecuáriaFloresta; contudo, apesar de ambas técnicas avaliadas apresentarem resultados precisos para predição do afilamento das árvores amostradas, a rede neural artificial prediz valores com maior precisão que a modelagem de efeitos mistos.

Palavras-chave: Biometria florestal, Inteligência artificial, Modelagem não linear mista.
\end{abstract}

\begin{abstract}
This paper aims to evaluate and compare the mixed effects modeling and artificial neural networks in order to estimate the taper of eucalyptus in integrated Crop-Livestock-Forestry (iCLF) systems. The data were collected in an experimental area of iCLF, implanted by the Brazilian Company of Farming Research - EMBRAPA Agrossilvipastoril, located in the municipality of Sinop, Mato Grosso State, Brazil. To reach the proposed aim, 165 trees with 51 months of age were scaled for the taper modeling with mixed effects models and artificial neural networks. The performance of these techniques was evaluated through precision measurements and graphical analysis. Mixed effects modeling and artificial neural networks are efficient and recommended in the estimative of taper of eucalyptus in integrated Crop-Livestock-Forestry system; however, despite both evaluated techniques present accurate results in predicting the taper of the sampled trees, the artificial neural network predicts values with greater precision than the modeling of mixed effects.

Keywords: Forest biometry, Artificial intelligence, Nonlinear mixed modeling.
\end{abstract}

\section{INTRODUCTION}

The growing demand for various products of agricultural and forestry origin has suggested alternative cultivations that aim for greater productivity. Among these alternatives, there is Crop-Livestock-Forestry integration systems (iLPF), which unite different production systems in a same area.

In these production systems, agricultural practices, trees, pastures, and animals are integrated to enhance ecological and economic interactions (TORRES et al., 2016). It is important to note that these systems of production have been growing through development programs, such as the Brazilian Low Carbon Agriculture Program (ABC), for example, which was implemented by the federal government of Brazil through Law No. 12,187 of December 29, 2009, establishing the National Policy on Climate Change (PNMC).

In this context, there is a need and interest on the part of forest producers and managers to manage the forest component, aiming at the quantification of production, since this information subsidizes forest planning. Thus, modeling techniques using statistics and computational tools are used to obtain accurate production estimates. Among the various techniques used in Brazil and in the world, there are the taper functions, which can be used for volumetric estimation and wood assortments.

FLORESTA, Curitiba, PR, v. 49, n. 3, p. 493 - 502, jul/set 2019.

Cerqueira, C. L. et.al.

ISSN eletrônico 1982-4688

DOI: 10.5380/rf.v49 i3.59504 
Additionally, the modeling of the stem form in populations established in monoculture is a subject sufficiently spread out in the Brazilian forest sector, with diverse studies developed and considered to represent the profile of the Eucalyptus species stem. Nonetheless, research on the shape of Eucalyptus clones' stems established in iCLF systems is still scarce. Regarding the use of new techniques for shaping the profile of the stem, Silva et al. (2016) obtained promising results with the use of artificial intelligence in iCLF systems. Therefore, the use of new modeling techniques can generate estimates with greater precision, such as mixed effects modeling (MEM) and artificial neural networks (ANN).

So, mixed effects modeling is a technique characterized by using linear or nonlinear models, depending on the objective under study, fixed, and random effects parameters, when having repeated measurements. According to Schabenberger and Pierce (2001), this technique should be used when there is a set of data that are grouped or that need to include random effects. In spite of the efficiency of MEM, this technique for tree tapering is relatively recent in forestry engineering, which is why there are few developed studies that employ it with taper functions; in this way, the studies of Sharma and Parton (2009) and Guangyi et al. deserve to be pointed out (2015).

In turn, artificial neural networks are computational models inspired by the nervous system of biological brains. Braga et al. (2007) have defined it as parallel systems consisting of simple processing units, also called artificial neurons, connected and operating specifically unidirectionally to perform certain mathematical functions. Hence, the fundamental elements of an ANN are the artificial neurons, arranged in one or more layers in a parallel form and interconnected by many connections (network), forming, consequently, the ANN system (SILVA et al., 2010).

The employment of ANN in forest science has confirmed the efficiency of this technique in several situations, with emphasis on estimates of dendrometric variables. Its use as a tool to estimate the diameter along the stem was considered efficient in studies carried out by Schikowski et al. (2015) and Martins et al. (2017) as well.

Given the importance of stem modeling studies in agroforestry systems, this article aimed to evaluate and compare the modeling of mixed effects and artificial neural networks to estimate the eucalyptus tapering in a CropLivestock-Forestry integration system.

\section{MATERIAL AND METHODS}

\section{Characterization of the study area}

The data for this study were obtained in two experimental areas of the Crop-Livestock-Forestry integration system (iCLF), called iCLF milk and iCLF cut, whose implantation was carried out by the Brazilian Agricultural Research Corporation (Embrapa Agrosilvipastoril) in the municipality of Sinop, in northern Mato

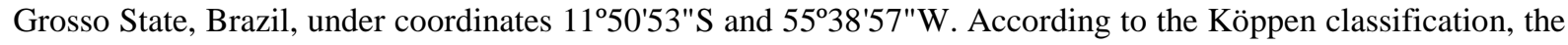
climate of the region is tropical type of monsoon, with three months of dry season and accumulated precipitation rainfall between 2,500 and $2,800 \mathrm{~mm}$ in the year. Along with, the average annual temperature is approximately 24 to $26^{\circ} \mathrm{C}$, with maximum and minimum temperatures close to 40 and $20^{\circ} \mathrm{C}$ respectively, and altitude of $380 \mathrm{~m}$ (ALVARES et al., 2013) in addition to a flat relief and predominance of clayey Oxisol.

The experiments were implemented in February (iCLF milk) and December (iCLF cut) of 2011, under a randomized block design (RBD) with three treatments: crop-livestock-forestry (T1); livestock-forestry (T2), and homogeneous planting of eucalyptus (T3). In treatment T1, it was adopted the planting arrangement of eucalyptus trees in triple rows consortium additionally to piatã grass pasture (Brachiaria brizantha cv. Piatã) and in integration with corn for silage, and catlle raising of Girolanda dairy cows as well. In treatment T2, the planting of trees in triple rows consortium with piatã grass (Brachiaria brizantha cv. Piatã) and cattle raising of Nellore for cut was adopted.

The treatments were established in different integration arrangements (Table 1). The forest component used was the hybrid clone Eucalyptus grandis x Eucalyptus urophylla and the planting orientation of trees in lines was in the East-West direction, both planted in grooves $30 \mathrm{~cm}$ deep.

Tabela 1. Descrição dos arranjos de integração e distribuição de frequência das árvores amostradas nos diferentes tratamentos.

Table 1. Description of the integration arrangements and frequency distribution of the trees sampled in the different treatments. 


\begin{tabular}{lcccc}
\hline Treatments & Space arrangement $(\mathbf{m})$ & $\mathbf{N}\left(\right.$ tree.ha- $\left.^{-1}\right)$ & $\mathbf{L}$ & $\mathbf{N}$ \\
\hline $\mathrm{T} 1$ & $3.0 \times 2.0 \times 15$ & 714 & 3 & 56 \\
$\mathrm{~T} 2$ & $3.5 \times 3.0 \times 30$ & 270 & 3 & 54 \\
$\mathrm{~T} 3$ & $3.5 \times 3.0$ & 952 & - & 55 \\
\hline Total & - & 1936 & - & 165
\end{tabular}

$\mathrm{N}\left(\right.$ tree.ha-1 $\left.^{-1}\right)$ : number of trees for hectare; tree: trees; N: number of cubed trees; e L: line number of plantation with trees in the treatments (T1 and $\mathrm{T} 2$ ).

\section{Database}

The data for accomplishment of this study had been gotten by means of cubage of 165 trees in the 51 months of age distributed between the studied treatments (Table 1). The cubed trees had been selected on the basis of diameter distribution (amplitude $=5$ to $23.7 \mathrm{~cm}$ ) of the proceeding treatments from the data of the forest inventory. The selected individuals were felled, sectioned and the diameters with bark were measured with the help of a caliper and tape in the following heights: $0.10 \mathrm{~m} ; 0.70 \mathrm{~m} ; 1.30 \mathrm{~m}$ and later in $1.0 \mathrm{~m}$ intervals up to a minimum diameter of approximately $1.0 \mathrm{~cm}$.

In each tree, in addition to the diameters (di) at various heights (hi), the diameter at $1.30 \mathrm{~m}$ from the ground level $(\mathrm{dbh})$ and the total height $(\mathrm{h})$ were measured. The individual tree volume, considered as real, was determined by the Smalian methodology.

\section{Stem Tapering}

The stem shape was evaluated using two techniques: mixed effects modeling (MEM) and artificial neural networks (ANN).

\section{Mixed Effects Modeling (MEM)}

The mixed effects modeling procedure was employed using the fifth degree polynomial (Equation 1) proposed by Schöepfer (1966) in order to obtain estimates of the diameter along the stem of the trees in different treatments.

$$
\frac{\mathrm{d}_{\mathrm{ij}}}{\mathrm{dbh}_{\mathrm{i}}}=\emptyset_{0}+\emptyset_{1} \mathrm{~T}_{\mathrm{ij}}+\emptyset_{2} \mathrm{~T}_{\mathrm{ij}}{ }^{2}+\emptyset_{3} \mathrm{~T}_{\mathrm{ij}}{ }^{3}+\emptyset_{4} \mathrm{~T}_{\mathrm{ij}}{ }^{4}+\emptyset_{5} \mathrm{~T}_{\mathrm{ij}}{ }^{5}+\varepsilon_{\mathrm{ij}}
$$

in which: $d_{i j}$ : bark diameter $(\mathrm{cm})$ of the $\mathrm{i}$-th tree at the $\mathrm{j}$-th height $(\mathrm{m})$; $\mathrm{dbh}_{\mathrm{i}}$ : diameter at $1.3 \mathrm{~m}$ from the ground level $(\mathrm{cm})$ of the i-th tree; $\emptyset$ : fixed and random parameters; $T_{i j}$ : relative height $\left(\frac{h i}{h}\right)$ of the $i$-th tree in the j-th position of the stem; and $\varepsilon_{\mathrm{ij}}$ : random error.

The fifth-degree polynomial was adopted because it is a non-segmented model widely used by professionals in the forest sciences and is frequently used in forest inventories when the objectives are to quantify multiproducts and evaluate the shape of the stem at different ages and spacings, it is due to the fact of the easiness of adjustment and precision that this model generally provides. The structure of the mixed tapping model used is represented in Equation 2.

$$
\emptyset=\left[\begin{array}{l}
\emptyset_{0} \\
\emptyset_{1} \\
\emptyset_{2} \\
\emptyset_{3} \\
\emptyset_{4} \\
\emptyset_{5}
\end{array}\right]=\left[\begin{array}{l}
\beta_{0} \\
\beta_{1} \\
\beta_{2} \\
\beta_{3} \\
\beta_{4} \\
\beta_{5}
\end{array}\right]+\left[\begin{array}{l}
\mathrm{b}_{0} \\
\mathrm{~b}_{1} \\
\mathrm{~b}_{2} \\
\mathrm{~b}_{3} \\
\mathrm{~b}_{4} \\
\mathrm{~b}_{5}
\end{array}\right]=\beta+\mathrm{b}
$$

in which: b-N $\left(0, \sigma^{2}\right)$; and $\varepsilon-\mathrm{N}\left(0, \sigma^{2} \mathrm{I}\right)$. The vector $\beta$ represents the fixed effects and the vector $\mathrm{b}$ the random ones.

The adjustment of the model was performed in a nonlinear form, applying the nonlinear mixed model (nlme), adopting as random effect the different treatments in order to increase the precision of the diameter predictions and to group the data obtained in the different spacings and integration arrangements.

FLORESTA, Curitiba, PR, v. 49, n. 3, p. 493 - 502, jul/set 2019. 


\section{Artificial Neural Networks (ANN)}

The ANNs were trained to obtain an ideal set of weights that provide good results for the prediction of diameters (di) along the bole (variable of the output layer), using as quantitative variables in the input layer the $\mathrm{dbh}, \mathrm{h}$, and hi and the treatments as categorical input. It was used the multilayered type of ANN (input, intermediate, and output) with supervised training and with the backpropagation error algorithm associated with the descending gradient, which has a universal capability to approximate functions (HORNIK et al., 1989).

The networks were trained with only one intermediate layer and the number of neurons ranging from 1 to 15 units. The activation function used in this layer was the hyperbolic tangent (Equation 3), while in the output layer the linear function was the one used (Equation 4).

$$
\begin{gathered}
f(\alpha)=\frac{e^{\alpha}-e^{-\alpha}}{e^{\alpha}+e^{-\alpha}} \\
(\alpha)=\sum_{s=1}^{s} x_{i} w_{i}+b_{s}
\end{gathered}
$$

in which: $\mathrm{f}(\alpha)$ : activation function; $\mathrm{x}_{\mathrm{i}}$ : vector of inputs; $\mathrm{w}_{\mathrm{i}}$ : vector of synaptic weights; and $\mathrm{b}_{\mathrm{s}}$ : bias.

The grid search method was used to obtain the weights, in order to minimize the predictions error. This method requires the definition of a set or sequence of values for each parameter, so that the search is performed by means of successive adjustments using all possible combinations of parameters (BERGSTRA; BENGIO, 2012).

Moreover, the ANN training consisted in the applying of the multiple cross-validation method $(k-f o l d)$ combined with the grid search one. According to Shalev-Shwartz and Ben-David (2014), the $k$-fold method consists of dividing the database randomly into $k$ subsets of similar dimensions and, for each configuration of the algorithm, perform $k$ trainings, separating one subset for validation at a time. Thus, all instances are used $k-1$ times for training and once for validation. The measure of accuracy of each configuration is obtained by the average of the mean squared error of the $k$ validations. After the cross-validation step, the algorithm performs the training of a final model for the best performance configuration using the entire set of training data.

As a result, the best configuration was the one that gave the model the smallest mean square error obtained by cross-validation with a maximum number of 3,000 cycles. The training was automatically interrupted by the algorithm when the accuracy of the model was not increased by 20 consecutive cycles. Nonetheless, the network training was performed in R programming language (R CORE TEAM, 2018) using the h2o package (THE H2o. AI TEAM, 2017) that performs the $k$-fold cros-validation automatically from the determination of the number of subsets (folds) by user, which in this study was defined as 5 folds. Therefore, the database was divided in 5 parts, being 4 for training and 1 for validation and so on until all the parts were trained and validated with each other. Finally, the best validated network was trained for the entire database.

\section{Accuracy statistics utilized}

Model adjustment, neural network training, and statistical procedures, were performed in Software R, version 3.4.4. The precision and accuracy of the modeling techniques were analyzed based on the following statistical criteria: Pearson's correlation coefficient $\left(\mathrm{r}_{\mathrm{yy}}\right)$, square root mean error (SRME\%), and graphical analysis of the residues in (E\%), calculated by Equations 5, 6 and 7, respectively:

$$
\begin{gathered}
r_{y y}=\left(\frac{\left[\sum_{i=1}^{n} y_{i} \hat{y}_{i}-\frac{\left.\sum_{i=1}^{n} \hat{y}_{i}\right)\left(\sum_{i=1}^{n} y_{i}\right.}{n}\right]^{2}}{\left[\sum_{i=1}^{n} y_{i}^{2}-\frac{\left(\sum_{i=1}^{n} y_{i}\right)^{2}}{n}\right]\left[\sum_{i=1}^{n} y_{i}^{2}-\frac{\left(\sum_{i=1}^{n} \hat{y}_{i j}\right)^{2}}{n}\right]}\right) \\
\text { RQEM } \%=\frac{100}{\bar{y}_{i}} \sqrt{\frac{\sum_{i=1}^{n}\left(y_{i}-\hat{y}_{i}\right)^{2}}{n}} \\
E \%=\left(\frac{y_{i}-\hat{y}_{i}}{y_{i}}\right) * 100
\end{gathered}
$$

in which: $r_{\mathrm{yy}}$ : Pearson correlation coefficient; $\hat{\mathrm{y}}_{\mathrm{i}}:$ estimated variable; $\mathrm{y}_{\mathrm{i}}:$ observed variable; $\bar{y}_{\mathrm{i}}:$ average of observed variable; SRME\%: square root mean error in percentage; and E\%: percentage residue. 


\section{RESULTS}

The diameter distribution of sampled trees has shown to be distributed symmetrical, when dbh classes were equal to $2 \mathrm{~cm}$. In order to characterize the variation of the stem's shape of these trees, a graph was plotted by height (hi) and diameter (di) along the stem, as well as with relativized di and hi variables (Figure 1).
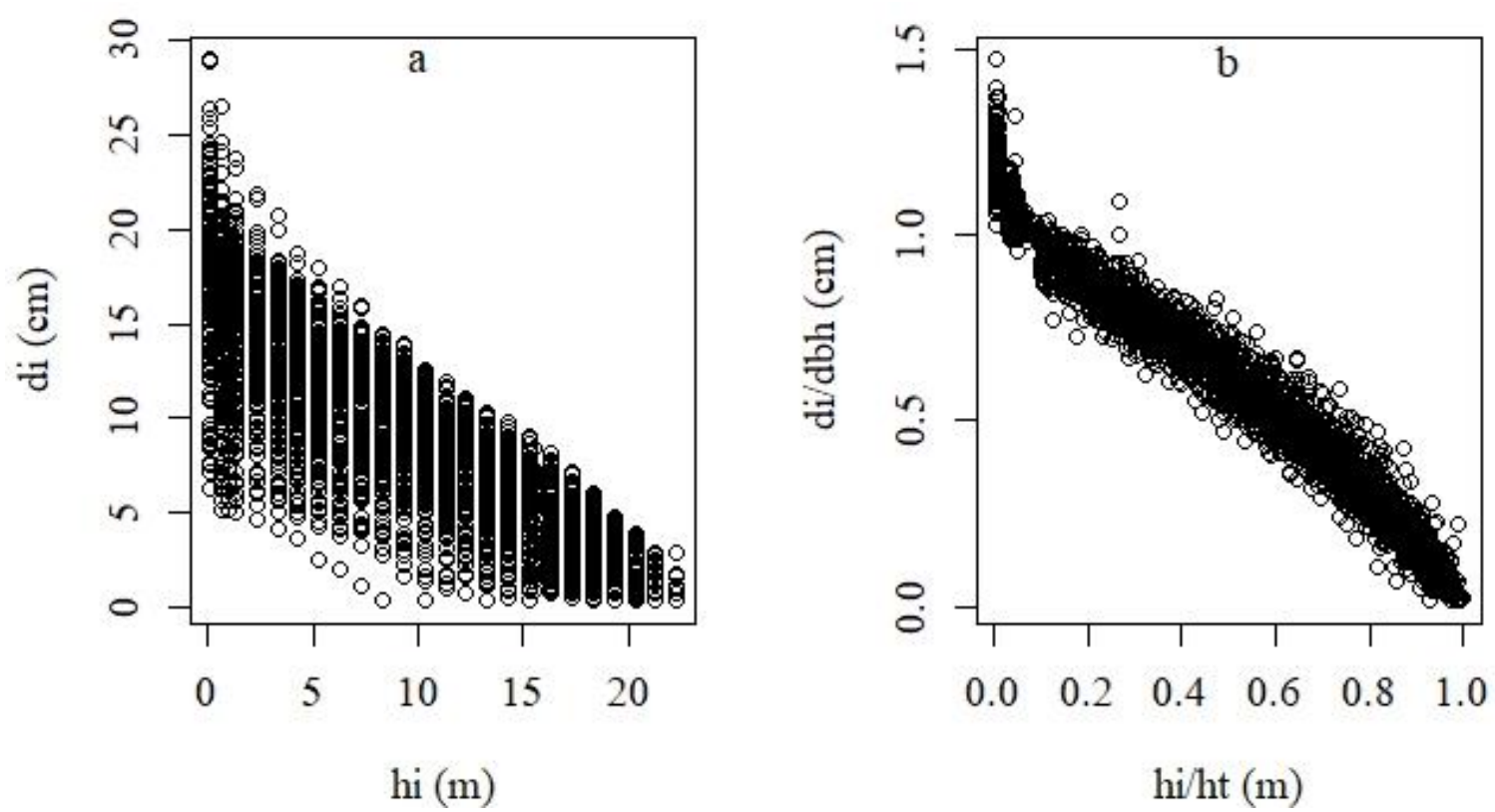

Figura 1. Variação do perfil do fuste das árvores amostradas. a: diâmetro por altura; b: diâmetro relativo por altura relativa.

Figure 1. Variation of stem profile of the sampled trees. a: diameter over height; b: relative diameter over relative height.

All fixed coefficients were significant and only the coefficient $\emptyset_{5}$ remained constant (Table 2), due to the attempt of adustment of the Schöpfer polynomial with all non-convergent random coefficients. As a consequence, only the coefficients from $\emptyset_{0}$ to $\emptyset_{4}$ were considered as random, which proves the variation of these between the treatments.

Tabela 2. Coeficientes fixos para todo o conjunto de dados e aleatórios por tratamento.

Table 2. Fixed coefficients for all data set and random by treatment.

\begin{tabular}{|c|c|c|c|c|c|c|c|}
\hline \multirow{2}{*}{ Model } & Treat. & $\emptyset_{0}$ & $\emptyset_{1}$ & $\emptyset_{2}$ & $\emptyset_{3}$ & $\emptyset_{4}$ & $\emptyset_{5}$ \\
\hline & \multicolumn{7}{|c|}{ Random parameters } \\
\hline \multirow{5}{*}{ Schöepfer } & $\mathrm{T} 1$ & 1.2120 & -3.4416 & 13.0674 & -27.8758 & 26.9320 & -9.9008 \\
\hline & $\mathrm{T} 2$ & 1.1990 & -3.5508 & 13.0676 & -28.0515 & 27.2022 & -9.9008 \\
\hline & $\mathrm{T} 3$ & 1.1738 & -3.3033 & 13.0674 & -28.4421 & 27.3921 & -9.9008 \\
\hline & \multicolumn{7}{|c|}{ Fixed Parameters } \\
\hline & $\mathrm{T}$ & $1.1949 *$ & $-3.4319 *$ & $13.0674 *$ & $-28.1231 *$ & $27.1754 *$ & $-9.9008 *$ \\
\hline
\end{tabular}

Treat .: treatments studied; $\emptyset_{\mathrm{i}}$ : estimated coefficients; and T: grouped data; *: significant at $5 \%$ probability.

All ANNs trained with the hyperbolic tangent activation function presented satisfactory results for estimating the diameters along the stem. The optimal weights and bias obtained for the best ANN are listed in Table 3.

FLORESTA, Curitiba, PR, v. 49, n. 3, p. 493 - 502, jul/set 2019.

Cerqueira, C. L. et.al.

ISSN eletrônico 1982-4688

DOI: $10.5380 /$ rf.v49 i3.59504 
Tabela 3. Pesos e bias obtidos para a melhor rede neural artificial treinada.

Table 3. Weights and bias obtained for the best trained artificial neural network.

\begin{tabular}{|c|c|c|c|c|c|c|c|c|c|}
\hline \multirow{3}{*}{ Neurons } & \multicolumn{7}{|c|}{ Weights } & \multicolumn{2}{|c|}{ Bias } \\
\hline & \multicolumn{6}{|c|}{ Intermediate layer } & \multirow{2}{*}{$\begin{array}{c}\begin{array}{c}\text { layer } \\
\text { output }\end{array} \\
\begin{array}{c}\text { di } \\
(\mathbf{c m})\end{array}\end{array}$} & \multirow{2}{*}{ b1 } & \multirow{2}{*}{ b2 } \\
\hline & T1 & $\mathbf{T 2}$ & T3 & $\begin{array}{l}\text { dbh } \\
(\mathrm{cm})\end{array}$ & $\begin{array}{c}\mathbf{H} \\
(\mathbf{m}) \\
\end{array}$ & $\begin{array}{c}\text { hi } \\
(\mathbf{m})\end{array}$ & & & \\
\hline 1 & -0.419 & -0.632 & 0.364 & 0.004 & -0.279 & 0.215 & -0.737 & -0.145 & 0.445 \\
\hline 2 & 0.354 & 0.401 & 0.530 & -0.165 & 0.359 & -0.812 & 0.980 & 1.194 & \\
\hline 3 & 0.527 & -0.221 & -0.084 & 0.118 & 0.209 & 0.246 & -0.364 & -0.087 & \\
\hline 4 & 0.301 & 0.272 & 0.173 & -0.170 & 0.066 & 0.763 & -2.265 & 1.144 & \\
\hline 5 & -0.453 & -0.251 & -0.135 & -0.619 & 0.302 & -0.260 & -0.541 & -0.381 & \\
\hline 6 & 0.657 & 0.479 & -0.541 & -0.158 & -0.035 & 1.640 & 0.519 & 0.601 & \\
\hline 7 & 0.341 & 0.288 & -0.336 & 0.281 & 0.103 & -0.306 & 0.752 & -0.517 & \\
\hline 8 & -0.843 & -0.394 & 0.281 & 0.075 & -0.080 & 0.315 & -0.608 & -0.211 & \\
\hline 9 & 0.721 & 0.780 & -0.926 & -0.043 & -0.230 & 0.337 & -0.895 & 0.085 & \\
\hline
\end{tabular}

T1: treatment 1; T2: treatment 2; T3: treatment 3; dbh: diameter at $1.3 \mathrm{~m}$ from ground level; h: total height; hi: height of sections; di: diameter of sections; b1: bias of the intermediate layer; and b2: bias of the output layer.

The results show that ANN with six neurons in the input layer, nine neurons in the middle layer and one neuron in the output layer provided the highest Pearson linear correlation coefficient and the lowest root of square error percentage when compared to the others, therefore, this was the selected one for comparison with mixed modeling (Table 4).

Tabela 4. Medidas de precisão da modelagem mista e rede neural artificial para estimativa dos diâmetros ao longo do fuste das árvores de eucalipto.

Table 4. Precision measurements of mixed modeling and artificial neural network to estimate the diameters along the stem of eucalyptus trees.

\begin{tabular}{lcc}
\hline Technique & $\mathbf{r}_{\mathbf{y y}}$ & SRME\% \\
\hline Mixed effects modeling & 0.98483 & 6.65 \\
Artificial neural network & 0.98609 & 6.34 \\
\hline
\end{tabular}

$\hat{r_{y y}}$ : Pearson correlation coefficient; and SRME\%: square root of mean error in percentage.

Based on the precision statistics, it is noted that the techniques of MEM and ANN present similar and accurate values, however, it is observed in these criteria that ANN has higher $\mathrm{r}_{\mathrm{yy}}$ and lower SRME\%, in addition to these measurements, the graphic analysis of the residues was used to compare both techniques (Figure 2). 
MEM

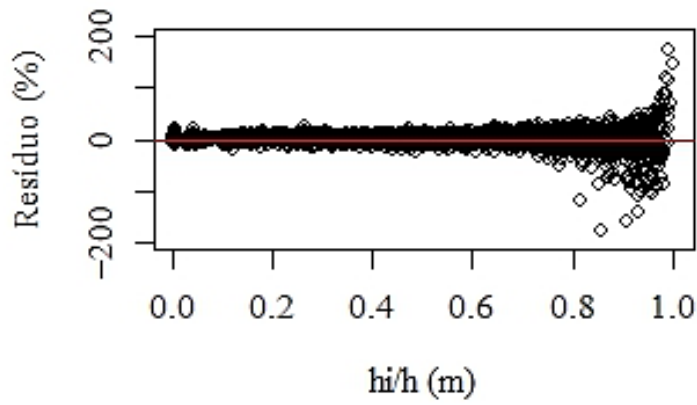

RNA

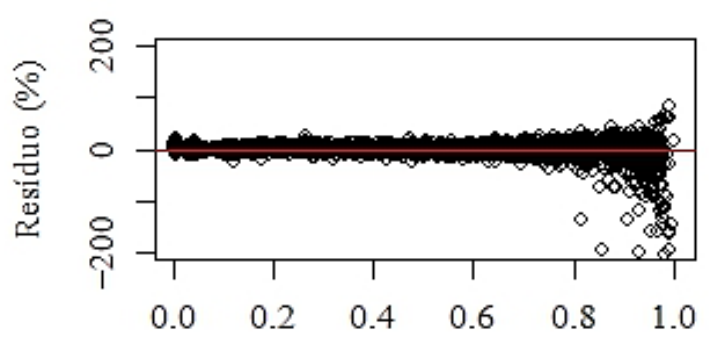

hilh (m)

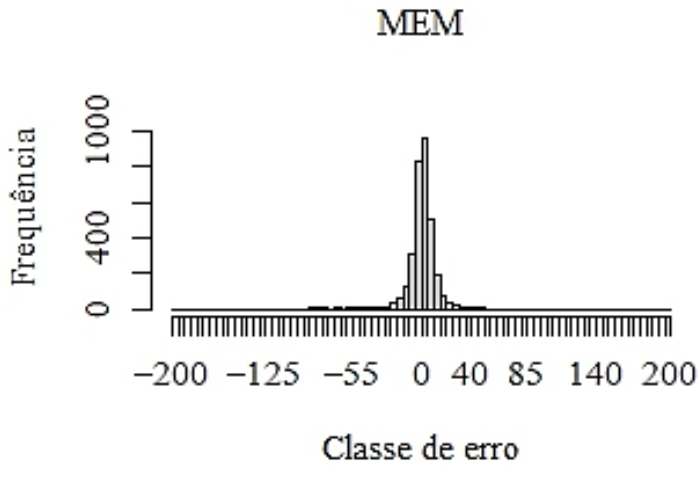

RNA

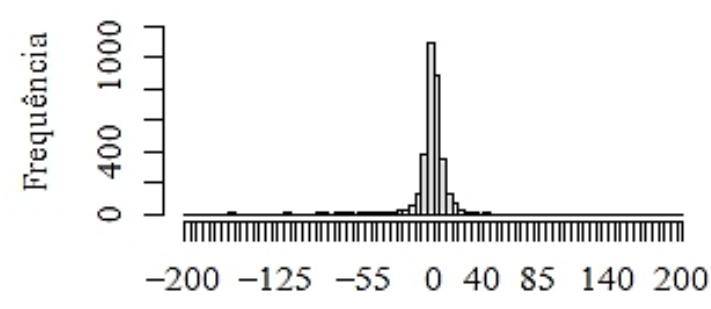

Classe de erro

Figura 2. Distribuição dos resíduos em percentagem e histograma dos erros para a modelagem de efeitos mistos e redes neurais artificiais.

Figure 2. Distribution of residuals in percentage and histogram of the errors for the mixed effects modeling and artificial neural networks.

The graphs of residuals allow to evaluate the behavior of errors along the stems and similarity is observed between MEM and ANN with adequate distribution along the regression line, indicating good accuracy between the observed and estimated values. Nevertheless, heterocedasticity is observed in the estimation made for the apical part of the trees, with greater dispersion generating, consequently, overestimation and underestimation. The histograms of residues showed a symmetrical and average distribution around 0 , confirming the accuracy of the evaluated techniques.

When plotting observed versus estimated values (Figure 3) of the techniques, it is possible to note that in both the dispersion occurs along the line that starts from the origin and forms an angle of 45 degrees. However, when considering the coefficient of determination $\left(\mathrm{R}^{2}\right)$ of straight lines means, the ANN mean has a higher value (0.99) when compared to the MEM (0.98), indicating that the observed and estimated values coincide.

\section{MEM}

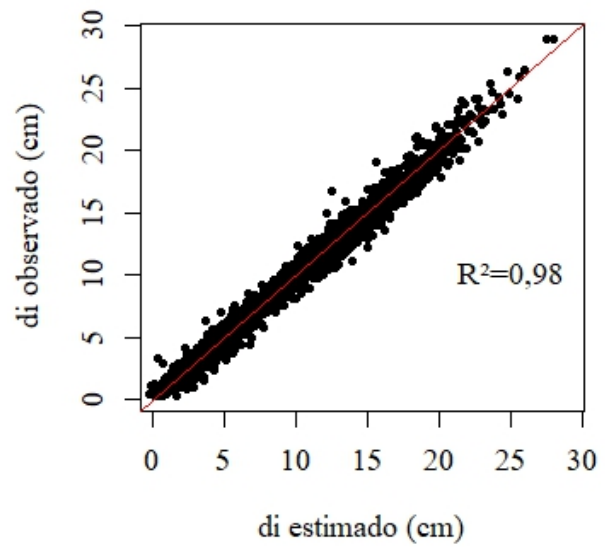

RNA

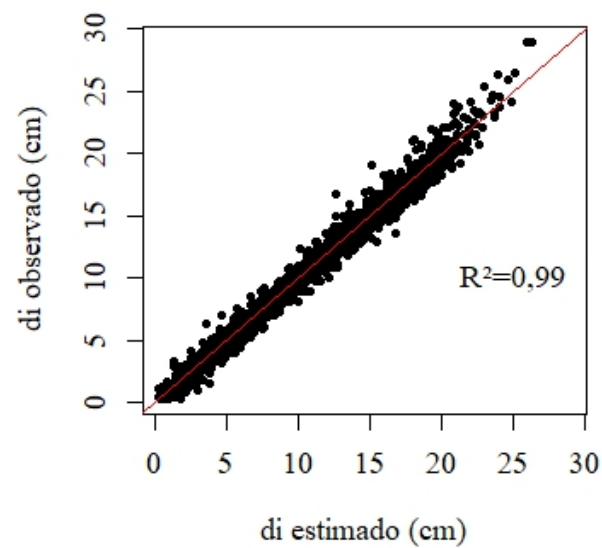

Figura 3. Diâmetro observado e diâmetro estimado pela MEM e RNA.

Figure 3. Diameter observed and diameter estimated by MEM and ANN.

FLORESTA, Curitiba, PR, v. 49, n. 3, p. 493 - 502, jul/set 2019.

Cerqueira, C. L. et.al.

ISSN eletrônico 1982-4688

DOI: $10.5380 /$ rf.v49 i3.59504 
The illustration of the tapering with the mean diameter along the stem of the observed and estimated values by MEM and ANN (Figure 4), confirms that both accurately estimated the profile of the mean tree. This affirmation is confirmed by the overlap of the curves, there is greater difference of MEM in the basal part of the stem.

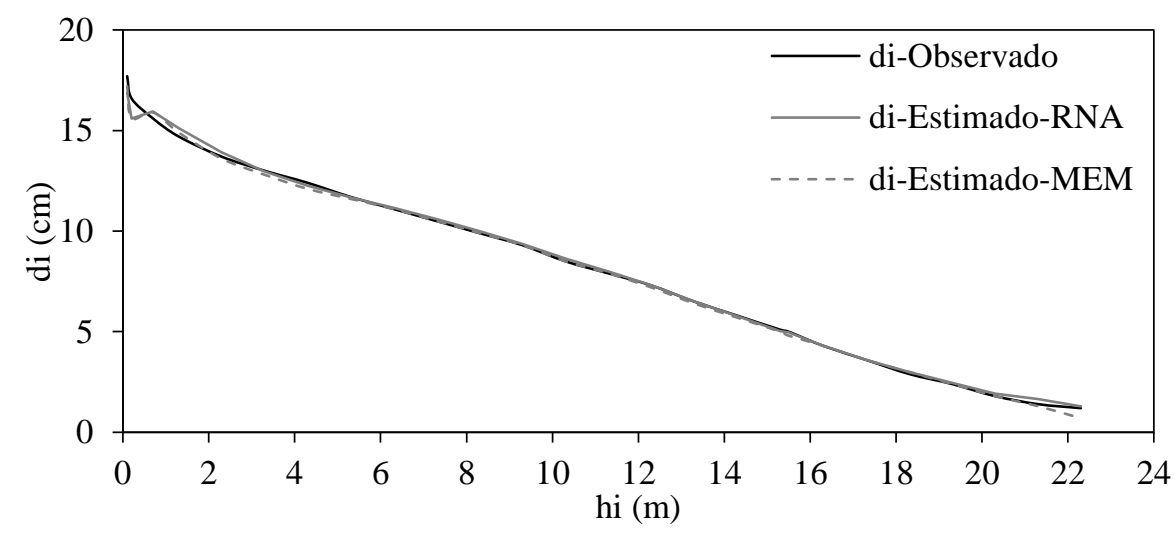

Figura 4. Perfil médio observado e estimado pela MEM e RNA.

Figure 4. Mean profile observed and estimated by MEM and ANN.

Based on the accuracy measurements, on the residual distribution, on the observed versus estimated data, and estimated curves of the mean tree profile, it is confirmed that the two techniques present accurate results for the tapering estimation of the sampled trees, being the ANN the one with a small superiority.

\section{DISCUSSION}

The shape of the tree stem is highly influenced by the spacing (SCOLFORO; THIERSCH, 2004), so, when considering it in the random effect of the mixed modeling and categorical variables of the artificial neural networks, it was possible to obtain more precise estimates.

Although the number of random parameters used in mixed modeling is directly related to the precision of estimates, when the model has a high number of parameters, the matrix procedure to be performed by the software is not feasible and in many cases there is no convergence, the ideal is to decrease the number of random parameters of the model.

The difficulty in estimating the smallest diameters in the stem's final portion is common in tapering studies (TÉO et al., 2013), and in other cases, errors may be accentuated at the base of the stems, as highlighted by Môra et al. (2014).

One of the advantages of ANNs is the use of many explanatory variables, providing to the training process greater agility and accuracy of estimates, thus eliminating the need for data layering. In this sense, Schikowski $e t$ al. (2015) studied the application of artificial neural networks for eucalyptus tapering and found satisfactory results, recommending its use with different network configurations, number of neurons, activation functions and variable parameters.

The accuracy of MEM observed in this study to predict the stem's shape has already been proven and reported by researchers who studied the shape of the stem with the application of random effects, among others, it is cited Cao and Wang, 2011.

Another important factor of MEM and ANN is the possibility of grouping data from different forest conditions (spacing, genetic material, site, diametric class, and age) and performing the adjustment procedure with a single database, reducing, then, the number of adjustments with time and accuracy gains; consequently, this reflects in the forest inventory costs. Additionally, these techniques allow to work with a set of data that do not meet some of the assumptions of the regression, such as: independence between observations, random, normal and identical distribution of the residuals, with zero mean and constant variance (LAPPI, 1991; SANQUETTA et al., 2015).

In turn, Cerqueira et al. (2017) evaluated the influence of spacing and planting arrangement on the eucalyptus tree shape and concluded that they influence in a significant way the shape of the tree stem and a single equation should not be adjusted to predict the tapering for global data that contemplate different arrangements in the iCLF system. 
Thus, the importance of studies with the application of mixed models and neural networks to predict the shape of the trees in order to optimize the wood assortments in iCLF is noteworthy. Another factor of great relevance is the possibility of reducing the number of sample trees for adjustments, since, according to Dorado $e t$ al. (2006), the use of the theory of mixed models makes it possible to reduce the sampling intensity required to fit models with adequate precision. Successively, Binoti et al. (2013) evaluated the reduction of costs in the forest inventory activity of eucalyptus stands and concluded that it is possible to reduce the number of measured heights without loss of precision in ANN estimates.

The reduction of the sampling intensity is extremely important for the forest measurement, especially when working with integrated systems of production, considering that they have a smaller amount of trees when compared to the conventional systems of production. Therefore, mixed effects modeling and artificial neural networks are important tools for estimating the sharpness and, consequently, the wood assortment of the trees, and can be used to support the forest management of eucalyptus in the iCLF system.

\section{CONCLUSION}

- The modeling of mixed effects and artificial neural networks are efficient and recommended for estimation of eucalyptus tapering in a Crop-Livestock-Forestry integration system.

- Both evaluated techniques present accurate and similar results for estimating the diameters along the stem of eucalyptus trees, with a slight superiority of the artificial neural network.

\section{REFERENCES}

ALVARES, C. A.; STAPE, J. L.; SENTELHAS, P. C.; GONÇALVES, J. L. M.; SPAROVEK, G. Köppen's climate classification map for Brazil. Meteorologische Zeitschrift, v. 22, n. 6, p. 711-728, 2013.

BERGSTRA, J.; BENGIO, Y. Random search for hyper-parameter optimization. The Journal of Machine Learning Research, Montréal, Canadá, v. 13, n. 1, p. 281-305, 2012.

BINOTI, M. L. M. S.; BINOTI, D. H. B. ; LEITE, H. G. ; SilVA, A. ; PONTES, C. R. . Aplicação de redes neurais artificiais para estimação da altura de povoamentos equiâneos de eucalipto. Revista Árvore, Viçosa, v. 37, p. 639-645, 2013.

BRAGA, A. P.; CARVALHO A. P. L. F.; LUDEMIR, T. B. Redes Neurais Artificiais: Teoria e Aplicações. Rio de Janeiro: LTC, 2 ed. 2007, 226 p.

CAO, Q. V.; WANG, J. Calibrating fixed- and mixed-effects taper equations. Forest Ecology and Management, Amsterdã, v. 262, n.4, p. 671-673, 2011.

CERQUEIRA, C. L.; MÔRA, R.; TONINI, H. Forma do fuste de eucalipto em diferentes arranjos de plantio e espaçamento. Advances in Forestry Science, Cuiabá, v. 4, n. 3, p. 137-141, 2017.

DORADO, F. C.; DIÉGUEZ-ARANDA, U.; ANTA, M. B.; RODRIGUEZ, M. S.; VON GADOW, K. A generalized height-diameter model including random components for radiata pine plantations in northwestern Spain. Forest Ecology and Management, Amsterdam, v. 229, p. 202-213. 2006.

GUANGYI, M.; YUJUN, S.; MIGUEL, S. A mixed-effects model with diferente strategies for modeling volume in Cunningghamia laceolata plantations. PLoS ONE, San Francisco, v. 10, n. 10, 2015.

HORNIK, K.; STINCHCOMBE, M.; WHITE, H. Multilayer feed forward network are universal approximators. Neural Networks, Bandera, v. 2, n. 5, p. 359-366, 1989.

LAPPI, J. Mixed linear models for analyzing and predicting stem form variation of Scots pine. Communicationes Instituti Forestalis Fenniae, v.134, p.1-69, 1986.

MARTINS, A. P. M.; DEBASTIANI, A. B.; PELISSARI, A. L.; MACHADO, S. A.; SANQUETTA, C. R. Estimativa do afilamento do fuste de Araucária utilizando técnicas de inteligência artificial. Floresta e Ambiente, Rio de Janeiro, v. 24, e20160234, 2017.

MÔRA, R.; SILVA, G. F.; GONÇALVES, F. G.; SOARES, C. P. B.; CHICHORRO, J. F.; CURTO, R. A. Análise de diferentes formas de ajuste de funções de afilamento. Scientia Forestalis, Piracicaba, v. 42, n. 102, p. 237-249, 2014.

FLORESTA, Curitiba, PR, v. 49, n. 3, p. 493 - 502, jul/set 2019.

Cerqueira, C. L. et.al.

ISSN eletrônico 1982-4688 
R CORE TEAM. R: A language and environment for statistical computing. Vienna, Austria: R Foundation for Statistical Computing. 2018. Disponível em: <https://www.R-project.org>. Acesso em: 25/03/2018.

SANQUETTA, C. R.; WOJCIECHOWSKI, J.; CORTE, A. P. D.; BEHLING, A.; PÉLLICO, S. N.; RODRIGUES, A. L.; SANQUETTA, M. N. I. Comparison of data mining and allometric model in estimation of tree biomass. BMC Bioinformatics, v. 16, n. 247, 2015.

SCHABENBERGER, O.; PIERCE, F. J. Contemporary statistical models: for the plant and soil sciences. Boca Raton: CRC Press, 1 ed. 2001, 760 p.

SCHIKOWSKI, A. B.; CORTE, A. P. D.; SANQUETTA, C. R. Estudo da forma do fuste utilizando redes neurais artificiais e funções de afilamento. Pesquisa Florestal Brasileira, Colombo, v. 35, n. 82, p. 119-127, 2015.

SCHÖEPFER, W. Automatisierung dês massen, sorten und wertberechung stender waldbestande schriftenreihe bad. Berlin: Wurtt-Forstl, 1966.

SCOLFORO, J. R. S. THIERSCH, C. R. Biometria florestal: medição, volumetria e gravimetria. Lavras: UFLA/FAEPE, 2004. 285 p.

SHALEV-SHWARTZ, S.; BEN-DAVID, S. Understanding machine learning: from theory to algorithms. New York: Cambridge University Press, 1 ed. 2014, 447 p.

SHARMA, M.; PARTON, J. Modeling stand density effects on taper for Jack Pine and Black Spruce plantations using dimensional analysis. Forest Science, Washington, v. 55, n. 3, p. 268-282, 2009.

SILVA, I. N. da; SPATTI, D. H.; FLAUZINO, R. A. Redes Neurais Artificiais para engenharia e ciências aplicadas. São Paulo: Artliber, 1 ed. 2010, 399p.

SILVA, S. NETO, S. N. O. LEITE, H. G.; OBOLARI, A. M. M.; SCHETTINI, B. L. S. Avaliação do uso de regressão e rede neural artificial para modelagem do afilamento do fuste de eucalipto em sistema silvipastoril. Enciclopédia Biosfera, Goiânia, v. 13, n. 23, p. 189-199, 2016.

TÉO, S. J.; MARCON, A.; EHLERS, T.; BIANCHI, J. C.; PElOSO, A. NAVA, P. R.; COSTA, R. H. Modelos de afilamento para Pinus elliottii em diferentes idades, na região de Caçador, SC. Floresta, Curitiba, v. 43, n. 3, p. 439-452, 2013.

THE H2O.ai TEAM. h2o: $\mathrm{R}$ Interface for H2O. 2017. Disponível em: <https://CRAN.Rproject.org/package=h2o>. Acesso em: 25/03/2018.

TORRES, C. M. M. E.; OLIVEIRA, A. C.; PEREIRA, B. L. C.; JACOVINE, L. A. G.; OLIVEIRA NETO, S. N.; CARNEIRO, A. C. O.; TORRES, C. M. M. E. Estimativas da produção e propriedades da madeira de eucalipto em Sistemas Agroflorestais. Scientia Forestalis, Piracicaba, v. 44, n. 109, p. 137-148, 2016. 